\title{
Relationship between Malaria and Sickle Cell Desease among Out-Patients Attending Genotype Test
}

\author{
Abdullahi, J.M. \\ Department of Biology, Kano University of Science and Technology, Wudil \\ P.M.B 3244, Kano- Nigeria
}

\section{Doi:10.5901/ajis.2013.v2n6p41}

\begin{abstract}
One hundred and eleven (111) out-patients attending Murtala Mohammad Specialist Hospital in Kano State Nigeria, with a mean age of 13.40 years and male to female ratio 25:12 were examined for malaria and sickle cell diseases. The blood sample of each patient from the tip of the thump finger pierced with lancet was collected in test tube containing sodium chloride and water in solution for haemoglobin genotype test and on slide for malarial parasite test, the samples collection was on weekly bases for a period of four weeks. The number of patients who were malaria infected was 70 with male-female ratio of 24:11 and non-malaria infected patients were 41. While number of normal haemoglobin ( $\mathrm{HbAHbA}$ ) patients was 63, sickle cell allele carrier were 32 (HbAHbs) and 16 sicklers (HbsHbs) with male-female ratio of 5:3. The sampled patients have $29 \%$ allelic frequency of sickle cell allele. The relationship between malaria and sickle cell disease that maintained sickle cell allele in malaria community did not differ significantly among the patients $(P>0.05)$.
\end{abstract}

Keywords: malaria, normal haemoglobin, sickle cell allele, haemoglobin genotype test, malarial parasite test.

\section{Introduction}

About $1 \%$ of all living birth produces children who suffer from genetic disorders (Taylor et.al., 2002). A high proportion of genetic mortality is due to such disorders. Sickle cell anaemia is one of the disorders. Any person may probably be a carrier of 4-8 different hereditary diseases which the person may not suffer but could pass on to children (Taylor et.al., 2002). Any gene can undergo mutation, some mutations are fatal, and some caused varying degree of harm while others are harmless, but all are generally referred to as genetic disease (Taylor et.al., 2002). Sickle cell disease is an excellent example of how a single mutation in a gene can have devastating consequences also it is an associate of natural selection in regulating how common a gene is in a population (Taylor et.al., 2002). Sickle cell disease occurs because of single amino acid change repeated in two beta chains of haemoglobin (Raven and Johnson, 1999). These chains are of 146 amino acids long, the fault occur at the sixth amino acid in the chains (Taylor et.al., 2002). In this change a valine replaces the usual glutamic acid at a location on the surface of protein near the oxygen-binding site, unlike glutamic acid, valine is non-polar (hydrophobic) it presence on the surface of the mole cule creates a sticky patch that attempt to escape from polar environment by binding to another patch, as long as oxygen is bound to the haemoglobin molecule there is no problem since the oxygen atom shield the critical area of the surface (Raven and Johnson, 1999). When oxygen level falls such as after exercise or at high altitudes oxygen is not so readily bound to haemoglobin and the exposed sticky patch then bind to similar patches on other molecule 
eventually producing long, fibrous clumps resulting into a deformed sickle-shaped red blood cell (Raven and Johnson, 1999). Malaria is a disease caused by species of plasmodium and one of the most fatal disease confronting human race in the tropics, subtropics and temperate region (Kashyap, 1997). It is a disease caused by microorganisms that live in person's red blood cells (Alters, 1996). Why is sickle cell allele not eliminated from the population by selection rather than being maintained (Raven and Johnson, 1992)? Apart from the fact that people who are heterozygous for sickle cell allele (Sickle cell allele carriers) best fit in the population exposed to malaria. Also for reasons that are not understood, women who are sickle cell allele carrier are more fertile than those who lack it (Raven and Johnson, 1992). This study was undertaken with the aim of determining the association of malaria and sickle cell in the distribution of sickle cell allele with the view of boosting the health condition and living standard of people by making awareness on the two diseases and the proper measures of preventing each of the diseases.

\section{Materials and Methods}

\subsection{Study Area}

Haemoglobin genotype test was conducted in the blood bank section laboratory, of Pathology Department at Murtala Mohammad Specialist Hospital Kano. The aspect of malaria parasite test was carried out in Biology laboratory of Kano University of Science and Technology Wudil, using dried blood films on slides taken from the hospital in slide box to university laboratory.

\subsubsection{Sample collection}

The tip of the thumb finger of one hundred and eleven (111) patients examined was pierced with a small blood lancet, five drops of blood were collected in a small test-tube containing sodium chloride and water in solution which was shook in order to mixed up the solution with the drops blood and placed in test tube rack for haemoglobin genotype test, a drop of blood was collected on a sterilized slide and spread filmily using a spreader for malarial parasite test. The target population were those attending genotype tests and the collection of samples was on weekly basis for a period four weeks.

\subsubsection{Haemoglobin genotype test}

This test was conducted using genotype machine which contained an electrophoresis tank of $40 \mathrm{x}$ $40 \mathrm{~cm}$ square in size and a height of $5 \mathrm{~cm}$ with a clear plastic lid, it was divided into two chambers (right and left) with a partition serving as a mounting stage. The chambers were partially filled with tris buffer solution into which a filter paper was soaked. Using a $1 \mathrm{ml}$ rubber pipette a blood sample was collected from a test tube and dropped on a stage of a tile containing fifteen (15) minute stages and one separate stage as a control, the pipette was rinsed with water before the collection of another blood sample from different test tube until all the stages had a drop. A metal teeth containing sixteen teeth corresponding to the stages on the tile was used to mixed drops of the blood samples at the same time. The pellet of the sample that followed each tooth was dropped on a cellulose acetate paper to made sixteen dots in straight lines, before the drop cellulose acetate paper was soaked in a solution of tris buffer in a container, it was brought out with forceps and blotted using blotting paper. The paper was mounted on the stage of the electrophoresis tank after the lid of the tank was took off, two plastic rods were fixed over the paper on the stage to held it in place and prevented it from shaking. The lid was used to covered the machine firmly which was switched on and left for 15 minutes. After the machine was switched off the cellulose acetate paper 
was brought out with the genotype status of fifteen patients which were examined depending on the number of dot appeared on a sample or the position of the dot on a sample. A dot of a sample tilted left indicated sickler (HbsHbs), a dot tilted right indicated normal ( $\mathrm{HbAHbA})$ and a dot divided into two indicated sickle cell carrier (HbAHbs).

\subsubsection{Malarial parasite test}

The blood film on slides were placed on rack, leishman stain in $1 \mathrm{ml}$ rubber pipette was used to stained them and left for 2 minutes; using buffer water the slides were flushed and left for 8 minutes to dry. Each slide was wiped with a cotton wool and placed on a cleaned paper, a drop of oil immersion was drop on the thin part of the treated sample and mounted on microscope with $\mathrm{x}$ 100 objective for observation of plasmodium which was identified in form of ring shape trophozoite stage of development as illustrated by (Symth, 1996).

\subsubsection{Data collection}

Collection of data was on weekly basis for a period of four weeks. The sexes of every individual examined as well as the age were recorded. The number recorded for an individual was equivalently with the numbering of haemoglobin genotype test which serially tallied with that of a slide for malarial parasite test, the data collected were subjected to chi-square test of association using WINKS software. The allelic frequency of sickle cell allele was found using the formula below and the male-female ratio was calculated using simple mathematical division.

$q=\underline{2 \times \text { number of homozygous recessive }+ \text { number of heterozygous }}$

$$
2 \times \text { total number }
$$

(Tamarin, 1996)

\section{Results}

Out of the 70 individuals observed with malaria infection only 12 were sicklers (HbsHbs), 38 have normal haemoglobin $(\mathrm{HbAHbA})$ and 20 were sickle cell allele carriers ( $\mathrm{HbAHbs}$ ) (Table 1 ). With regards to non-malarial infected in the 41 individuals recorded only 4 were sicklers (HbsHbs), 25 of them has normal haemoglobin ( $\mathrm{HbAHbA})$ and 12 were sickle cell allele carriers ( $\mathrm{HbAHbs})(\mathrm{Table} 1)$. The prevalence of malaria infection among the individuals stood at $63.1 \%$ that of sicklers $14.4 \%$, normal haemoglobin $56.8 \%$ and sickle cell allele carrier $28.8 \%$ (Table 1 ). Highest number of normal patients with malaria and no malaria was observed this was followed by sickle cell carrier patients with malaria and no malaria. The least number of patients were observed in sicklers whom were non-malaria infected (Table 1). From the male-female ratio of 25:12 with the mean age 13.40 of the total sampled patients observed, $54.1 \%$ were children, $12.6 \%$ were teenagers and $33.3 \%$ were adults (Table 2). It was observed that the male-female ratio of 5:3 were sicklers and malefemale ratio of 24:11 were malaria infected (Table 3 and Table 4). The association of malaria and sickle cell disease in the propagation of sickle cell allele was not significantly different at the level of the patients $(P>0.05)\left(x^{2}=1.187\right)$.

Table 1: 2 x 3 contingency table with number of patients in comparism between malaria and haemoglobin genotype and their percentages.

\begin{tabular}{cccccc}
\hline $\begin{array}{c}\text { Malarial } \\
\text { parasite test }\end{array}$ & $\begin{array}{c}\text { Haemoglobin } \\
\text { HbAHbA (normal) }\end{array}$ & $\begin{array}{c}\text { Genotype } \\
\text { HbAHbs (carrier) }\end{array}$ & $\begin{array}{c}\text { Test HbsHbs } \\
\text { (sickler) }\end{array}$ & Total & (\%) \\
\hline $\begin{array}{c}\text { Malaria } \\
\text { infected }\end{array}$ & 38 & 20 & 12 & 70 & 63.1
\end{tabular}




\begin{tabular}{cccccc}
$\begin{array}{c}\text { Non-malaria } \\
\text { infected }\end{array}$ & 25 & 12 & 4 & 41 & 36.9 \\
$\begin{array}{c}\text { Total } \\
\text { Prevalence }\end{array}$ & 63 & 32 & 16 & 111 & - \\
$(\%)$ & 56.8 & 28.8 & 14.4 & - & - \\
\hline
\end{tabular}

Table 2: Sampled patients age range and number of male and female

\begin{tabular}{ccccc}
\hline Gender & $\begin{array}{c}\text { Children } \\
\text { 0-9 year }\end{array}$ & $\begin{array}{c}\text { Teenage } \\
10-19 \text { year }\end{array}$ & $\begin{array}{c}\text { Adult } \\
\text { 20 year-Above }\end{array}$ & Total \\
\hline Male & 36 & 7 & 32 & 75 \\
Female & 24 & 7 & 5 & 36 \\
Total & 60 & 14 & 37 & 111 \\
$\begin{array}{c}\text { Percentage } \\
(\%)\end{array}$ & 60 & 31 & 16 & - \\
\hline
\end{tabular}

Table 3: Number of male and female patients with the various haemoglobin genotypes

\begin{tabular}{cccc}
\hline Gender & $\mathrm{HbAHbA}$ & $\mathrm{HbAHbs}$ & $\mathrm{HbsHbs}$ \\
\hline Male & 44 & 21 & 10 \\
Female & 16 & 10 & 6 \\
Total & 60 & 31 & 16 \\
\hline
\end{tabular}

Table 4: Number of male and female infected with malaria and non-infected with malaria

\begin{tabular}{ccc}
\hline Gender & Malaria infected & $\begin{array}{c}\text { Non-malaria } \\
\text { infected }\end{array}$ \\
\hline Male & 48 & 28 \\
Female & 22 & 13 \\
Total & 70 & 41 \\
\hline
\end{tabular}

\section{Discusssion}

The significance of the study was to find out if a relationship exists between the distribution of a pathogenic disease and a genetic disease in maintaining a fatal allele in malaria striking communities. The result obtained indicates no relationship between the malaria disease and sickle cell disease among the sample of patients examined. This disagreed with Tamarin (1996) reported that in search for an answer to a question (what could possibly maintain the detrimental allele of sickle cell?). He found that the distribution of sickle cell allele coincide well with the distribution of malaria. Malaria a disease easily spread by a vector insect known as Anopheles female mosquito that reproduce easily due to the conducive atmosphere of these regions could not be compared in terms of distribution with a heritable disease that was only transferred from two parents (male and female) to offspring. The sicklers and sickle cell carrier patients were also observed with malaria infection. In line with this Ibidapo and Akinyanju (2000) reported that out of the 102 adolelescents and adults with sickle cell anaemia presented to the emergency unit of a Lagos hospital sixty-three per cent had infection which was malaria in $24.5 \%$ etc. Malaria infect all patients at a rate higher than that of the sickle cell allele as such the sicklers and the sickle cell carrriers suffer from malaria fever. The allelic frequency of the sickle cell allele among the patients was found to be $29 \%$, this 
allelic frequency could be rated moderate when compared with the findings of Taylor et.al., (2002) reported that the frequency of the allele of sickle cell may reach $40 \%$ in some part of Africa. The population of patients with sickle cell disease in the period of four weeks was $14.4 \%$ this is low when compared with the work of Mader (1998) reported that as a many as $60 \%$ of populations in malaria infected region of Africa have the sickle cell allele. Lack of awareness on the disease could lead to the maintenances and the distribution of the allele in these regions. The male-female ratio $5: 3$ of sickle cell anaemia patients examined in the study was in disparity with Ibidapo and Akinyanju (2002) reported that the male-female relation of sickler patient of a Lagos hospital was 1:5. However, a number of biological, social, political and cultural backgrounds may affect the male-female ratio in different areas.

\section{Conclusion}

In conclusion there is no selection for sickle cell allele (no any of the three genotypes fit) in malaria striking area since all are at risk of malaria, there are high records of death toil with regard to malaria only few were mentioned in case of sickle cell disease, The prevalence of sickle disease could be reduce by enlighten campaign and researches to come up with anti-sickling drugs but malaria is serious pathogenic disease in which much has to be done by the general public in reducing its spread.

\section{Recommedations}

For the fight against the two diseases to reduce their prevalence it is recommended that individuals should modify their environment by improving land drainage as well as improving housing of man and animals. Government should also revise the services of public health inspectors so that they impose individuals on modifying their environment in fight against the spread of malaria by anopheles mosquitoes. There is a need for government to use media to broadcast the importance of haemoglobin genotype test for each and every individual and make it free. The media should alert the public about the competent genotype to engage in marriage.

\section{References}

Alters, S. (1996): Biology Understanding Life, printed in the United tate of America P. 250.

Ibidapo, M. O. and Akinyanju, O. O (2000) Acute Sickle Cell Syndromes in NigerianAdults. PubMed-index for MEDLINE 3:151-155available at www.ncbi.nlm.nih.gov/entrez/query.fcgi?CMD=Display\& $\mathrm{DB}=$ pubmed accessed on 20-3-2006, 2:30pm.

Kashyap, V. (1997): Life of invertebrates, second revised edition, printed at Phashupati Printer's dallui110032 , P. 53.

Madar, S. S. (1998): Biology 6th edition, printed in a United State of America P. 237.

Raven, P. H and Johnson, G. B. (1992): Biology, 3rd edition, printed in the United State of America, PP. 380 and 387.

Raven, P. H and Johnson, G. B. (1999): Biology, 5th edition, printed in the United State of America, PP. 54 and 406.

Symth, J. D. (1996): Animal parasitology, low price edition, printed in Great Britain at University Press Cambridge, PP. 127 and 133.

Tamarin, R. H. (1996): Principle of genetics, 5th edition, printed in the United States of America PP. 406, 558, 562 and 577.

Taylor, D. G, Green, N. P. 0 and Stout, G. W. (2002): Biological Science, reprintededition, printed in India at multiwista limited PP. 857-860. 
